\title{
Tracing Mercado's Anthropological Perspective (First of Two Parts)
}

\section{Emmanuel D. Batoon}

\begin{abstract}
The paper traces the significance of Leonardo N. Mercado's anthropological perspective on the study of Filipino philosophy and argues that the significance of his perspective lies in its bringing to light the Filipino people as a group of philosophers in their own right who constructed a worldview of their own and embodied it in their languages, behavior, and mythology that provides them with a mission and vision as a nation. To justify the argument, a content analysis of the book Elements of Filipino Philosophy was done in terms of Mercado's cultural philosophical theoretical framework, where philosophy is constructed by a group of ordinary people like Filipinos and the result is an empirical and observably unique but not idiosyncratic worldview like the Filipino worldview, ethnographic method that involves an ethno-linguistic analysis of the major Philippine languages, phenomenological observation of Filipino behavior, secondary data analysis of social scientist's analysis of Philippine mythologies, and findings on the conceptual elements of the Filipino worldview composed of a logos that describes the mode through which Filipinos construct their world, ontos that describes Filipinos' constructed world, theos that describes how Filipinos construct a sacred world, and ethos that describes how Filipinos construct a moral world. To extend the argument of the discourse, a rejoinder is provided in response to scholars' criticisms and approval of Mercado's anthropological perspective on the study of Filipino philosophy.
\end{abstract}

Keywords: Mercado, Filipino philosophy, cultural philosophy, ethnographic method

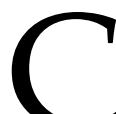

omments and misconceptions regarding how bad Filipinos are have become commonplace. The Filipino culture can be the easiest scapegoat for all that went wrong with the Filipino. But one gets

(C) 2014 Emmanuel D. Batoon

http://www.kritike.org/journal/issue 14/batoon june2014.pdf

ISSN 1908-7330

$(\mathrm{Cc}) \mathrm{BY}_{\mathrm{B}-\mathrm{NC}}$ 


\section{MERCADO'S ANTHROPOLOGICAL PERSPECTIVE}

startled when somebody comes along, celebrating the best in the Filipino. Such is what Fr. Leonardo N. Mercado, SVD does in his book, Elements of Filipino Philosophy. ${ }^{1}$

The paper explores the significance of Mercado's anthropological perspective on the study of Filipino philosophy and contends that the import of his viewpoint lies in its bringing to light the Filipino people as philosophers in their own right. As such, they have formed a worldview of their own, embodied it in their language and behavior, and articulated it into a national mission and vision.

Supporting the argument, an explanatory content analysis ${ }^{2}$ of the book, Elements of Filipino Philosophy is done following Mercado's theoretical framework, method, and findings on the conceptual elements of the Filipino worldview. To further justify the argument of the paper, a rejoinder is provided on scholars' criticisms and approval of Mercado's anthropological perspective on the study of Filipino philosophy.

In consonance with Mercado's style of presentation and intention to communicate his findings on the elements of Filipino philosophy to those who are primarily learned in Western academic philosophy, the presentation of the findings in each section of this study also begins with a summary of Western academic philosophical perspectives and ends with a summary of the Filipino cultural philosophical perspective.

\section{Theoretical Framework: Cultural Philosophy}

Philosophy can be viewed from an academic perspective and from a cultural perspective. Academic Philosophy is made by scholars who devote and dedicate their lives in formulating formal philosophies. The epistemic product of a scholar is a philosophical theory that is supposed to be universal in scope, encompassing the life of mankind. The conceptual elements that comprise a philosophical theory are the concepts of being, consciousness, cosmos, man, ethics, and social life.

The traditional method that professional philosophers use is the historical interpretive method. ${ }^{3}$ The method uses philosophical texts as data and the interpretation takes the form of a synthesis of previous thinkers' philosophical concepts in order that a new theory may be formulated, or the meaning of a philosopher's theory may be elaborated, an unknown thought

\footnotetext{
${ }^{1}$ Leonardo N. Mercado, Elements of Filipino Philosophy (Tacloban City: Divine Word University Publication, 1974).

${ }^{2}$ W. Lawrence Neuman, Social Research Methods Qualitative and Qualitative Approach $6^{\text {th }}$ ed. (Boston: Pearson Education, Inc., 2006), 44-45.

${ }^{3}$ Emmanuel D. Batoon, A Guide to Thesis Writing in Philosophy Part One: Proposal Writing (Manila: REJN Publishing, 2005).

(C) 2014 Emmanuel D. Batoon http://www.kritike.org/journal/issue 14/batoon june2014.pdf ISSN 1908-7330
} 
element elucidated, the sources examined, the premises critiqued or defended, or a weak theory reconstructed. To facilitate the formulation of a universal and normative theory, academic philosophers invent a technical language and logic. The result of the study is usually expressed in a formal prose essay originally called a treatise but presently called a thesis.

Varied philosophical theories have been formulated and written in Western history of philosophy. The variations of these philosophical theories can even be used to distinguish the periods of the history of Western philosophy. During the Ancient-medieval period philosophers defined their discipline as the science of being as being. But modern philosophers redefined their discipline into an "inquiry regarding the workings of consciousness"; and contemporary philosophers further redefined their discipline into "an analysis of ordinary language" in terms of its logic, its use in the pragmatics of communication, and its use in the interpretation "in" being. ${ }^{4}$

Meanwhile, a cultural philosophy is a philosophy sui generis and not merely an appendix of academic philosophy because it is constructed by a group of ordinary people (ethnos) that results in an empirical and observably unique but not idiosyncratic worldview, in contrast to the philosophy constructed by academic scholars that lead to the formulation of an abstract and speculative theory that claims universality with a priori validity.

Ordinary people begin their philosophical inquiry from their collective psychological need to have a reason for being and staying together; they need to have a common mission to construct their reality that leads to a common vision of who they could be. Anthropologists Hoebel and Frost describe a people's worldview in this way:

The cognitive view of life and the total environment which an individual holds or which is characteristic of the members of a society is frequently referred to as Weltanschauung or world view. World view carries the suggestions "of the structure of things as man is aware of them," and it is thus the life scene as people look out upon it. It is the human being's inside view of the way things are colored, and arranged according to personal cultural perceptions. ${ }^{5}$

\footnotetext{
${ }^{4}$ Aldo Tassi, "Modernity as Transformation of Truth into Meaning," in International Philosophical Quarterly, 22 (1982), 185-194.

${ }^{5}$ Adamson E. Hoebel and Everett L. Frost, Cultural and Social Anthropology (New York: McGraw-Hill Book Company, Inc., 1976), 323-324.
} 


\section{MERCADO'S ANTHROPOLOGICAL PERSPECTIVE}

A people constructs a worldview through interpersonal communication and reflection using ordinary language and psychological intuition. A people's inside view of the way things are shows that they have a common mind that gives them a common mode of constructing a world (logos), a common construction of a world (ontos) that consists of man (anthropos) and nature (cosmos), a common way of organizing social relations (socius), a common construction of a sacred world (theos), and a common construction of a moral world (ethos). They in turn embed this constructed world in their ordinary language, behavior, and oral literature like maxims, proverbs, and myths.

Scholasticism and Existentialism were the popular academic philosophies in Mercado's time. On one hand, Scholasticism defines philosophy as the science of things by their ultimate principles and takes the study of being as the center of the philosophical universe. On the other hand, Existentialism defines philosophy as search for the meaning of individual existence and focuses on the individual's existence as the central theme around which the other themes on epistemology and ethics revolve.

Mercado characterized these philosophies as philosophies that "belong to the educated and the elite, who have some leisure time after working for a living." 6 Mercado opted for a "third way of looking at philosophy that to him is not elitist but anthropological."7 He says:

Anthropologists tell us that every people has its own existential postulates. This third meaning of philosophy is concerned with a particular group of people's world view and is the reason behind the people's way of thinking and behaving. ${ }^{8}$

Thus, Mercado uses the cultural definition of philosophy as his framework in understanding Filipino philosophy. But, who is this Filipino? Mercado says the following:

Perhaps the criterion of nationhood is centralized government extended over a geographical area. Although the Philippines may have different ethnic groups, there has been a growing national awareness among its citizens which transcends regionalism. Perhaps, we can use the working definition of 'Filipino'

\footnotetext{
${ }^{6}$ Mercado, Elements of Filipino Philosophy, 4.

${ }^{7}$ Ibid.

${ }^{8}$ Ibid.
}

(C) 2014 Emmanuel D. Batoon

http://www.kritike.org/journal/issue 14/batoon june2014.pdf

ISSN 1908-7330

(cc) BY-NC 
given in the Article III of the 1973 Constitution of the Philippines:

Section 1. The following are citizens of the Philippines:

(1) Those who are citizens of the Philippines at the time of the adoption of this Constitution.

(2) Those whose fathers and mothers are citizens of the Philippines.

(3) Those who elect Philippine citizenship pursuant to the provisions of the Constitution of nineteen hundred and thirty-five. ${ }^{9}$

Why does Mercado rely on this legal definition of the Filipino and not otherwise? It is because this definition covers Filipinos in general - the masses and the elite, the educated and the uneducated alike. In choosing this definition, Mercado emphasizes the fact that Filipino philosophy is by Filipinos, of Filipinos, and for Filipinos as a cultural group.

Is this not too wide a definition of the term "Filipino"? Is it not the case that Filipino philosophy is but a constructed appellation that people ascribe to an individual who has asked authentic questions about his or her life experience and produced great insights about the meaning of life?

This may ring true to academic philosophical theories, but this is not necessarily true if we are talking about philosophy as a group of people's worldview, like the Filipino worldview. Here, the focus is on Filipinos as a cultural group of philosophers, not on an individual Filipino thinker who attempts to formulate a philosophy for mankind.

Is it possible that the thought of a prominent Filipino, like those of the Filipino national heroes', stands for Filipino philosophy? Mercado gives the following qualified response:

It is the philosophy of the masses first of all, and not what Rizal, Mabini or other Filipino elitist thinkers have thought of, except when these thoughts reflect the viewpoint of the masses. ${ }^{10}$

In saying that Filipino philosophy is the philosophy of the masses, Mercado is distinguishing the empirical operative philosophy of ordinary Filipinos as a group of people from the idealized speculated philosophy for

\footnotetext{
${ }^{9}$ Ibid., 5.
}

${ }^{10}$ Ibid., 4.

(c) 2014 Emmanuel D. Batoon http://www.kritike.org/journal/issue 14/batoon june2014.pdf

ISSN 1908-7330 


\section{MERCADO'S ANTHROPOLOGICAL PERSPECTIVE}

Filipinos. This is why he does not necessarily accept that the philosophies of Rizal or Mabini stand for Filipino cultural philosophy because they are known to have espoused the philosophies of the western enlightenment philosophers to serve their ideals of reform and/or revolution. Nonetheless, Mercado still entertains the possibility that some Filipino thinkers may express the Filipino masses' philosophy. One point of contention rests in the question: Are the Filipino masses really capable of constructing their own philosophy?

Ramon Reyes wrote an article on the sources of Filipino thought. He begins with a distinction between vital thought and reflexive thought:

In general, the thought of a people develops in two basic stages: first, in the form of what we might call vital thought by which immediate experience attains a preliminary structuration and verbalization by way of myth, ritual, song and language, folk-tale, traditional sayings and aphorisms, customary legal, political and religious codes; secondly, in the form of a more reflexive, more mediate type of thought, whether conscious or unconscious, analyzing, systematizing and justifying a vital thought that has reached a high point of growth and therefore, of conflict, thereby demanding reintegration, a critical evaluation of its boundaries and particular strengths in view of the ulterior possibilities of man. ${ }^{11}$

Then, he sketches the so-called "Filipino vital thought"12 and speculates on "how the Filipino reflexive thought"13 develops. He claims that it is "engendered by the evolution and maturation of the historical situation itself." 14 This implies that vital thought and reflexive thought are mutually exclusive and that before ordinary Filipino can philosophize, they have to develop reflexive thinking abilities first. But how true is this?

Reyes' distinction is only a distinction in thought but in empirical cultural practice, vital thinking and reflexive thinking occur at the same time. The anthropologist Paul Radin, in his study entitled Primitive Man as Philosopher, ${ }^{15}$ finds that the primitive man not only has vital thought on man,

${ }^{11}$ Ramon C. Reyes, "Sources of Filipino Thought," in Philippine Studies, 21 (1973), 429430.

\footnotetext{
12 Ibid., 430-434.

${ }^{13}$ Ibid., 434.

${ }^{14}$ Ibid.

${ }^{15}$ Paul Radin, Primitive man as philosopher (New York: Dover Publications, Inc., 1957).
} 
the world, death, and thoughts on right and wrong but also demonstrates reflexive thinking on substantive concerns like reality and the external world, the nature of ego and of the human personality, the nature of God, as well reflexive thinking on methodological issues like the nature of speculation for its own sake, systematization of ideas, and skepticism and critique.

If the primitive man can produce both vital thought and reflexive thought at the same time, how much more can the modern Filipino produce both thoughts at the same time? Felipe Landa Jocano, a respected Philippine anthropologist, corroborates this claim in his study on the Filipino worldview:

One thing we have learned from our worldview project is that knowledge and sophisticated thinking do not belong exclusively to the formally educated, the middle class, or the urban cities. There are rural villagers whose understanding of the ideas, the images, and the metaphors of their traditions makes local ways coherent and rational. ${ }^{16}$

One may persist in his or her skepticism about the capacity of the ordinary Filipino to philosophize by asking: "Are Filipinos really capable of making their own philosophy when theirs is an oral culture?"17Abulad is of this mindset. He says:

...What will deserve the name of Filipino Philosophy, as we see it, will eventually be comprised of our written philosophy. To be sure, there is and there has always been a Filipino philosophy, if only because no people are known to survive without an implied metaphysics. But such a philosophy which spring from the people's natural disposition is not sufficient to establish the worth of a nation. There is also a need for a more consciously developed system of thought, one that results from the deliberate sifting of ideas of thinker's mind. In other words, the demand is for written philosophy. Writing gives our ideas their permanence and as such expose our intellectual strengths and weaknesses before a competent audience.

${ }^{16}$ Felix L. Jocano, Filipino Worldview (Quezon City: PUNLAD, 2001), 12.

17 F.P.A. Demeterio III, “Re-reading Emerita Quito's Thoughts Concerning the Underdevelopment of Filipino Philosophy," in F.P.A. Demeterio's Philosophy and Cultural Theory Page. 
Our books lay our souls open for scrutiny, and there is no escaping the judgment of all. Publication exposes not only our merits but also our pitfalls. History will decide if we have made a contribution not only to Filipino philosophy but to the World of Philosophy as well. ${ }^{18}$

Indeed, literacy is a requirement for the formulation of an academic philosophical theory because it is the only way to preserve a highly abstract set of complex ideas that serves as the mental frame of mankind. But making literacy a requirement in formulating a cultural philosophy meant for a group of people has no empirical cultural grounding. In fact, oral literature is a more efficacious way of expressing a people's worldview compared with written literature because of its immediate and personal effect among consociates. But assuming that there is indeed a Filipino philosophy, how does this compare with western and oriental peoples' cultural worldviews?

As asserted earlier, a cultural philosophy expresses the unique worldview of a group of people; hence, the Filipino worldview is a unique worldview compared with the worldviews of people in other parts of the globe. So Filipino philosophy can neither be denigrated as lower nor privileged as higher than any of the other cultural philosophies. Filipino philosophy though unique, however, bears family resemblances with other cultural philosophies like that of the Malay and the Chinese to mention a few. This is why Mercado took the liberty of using the groups of people's philosophies to shed light on the "shadows" in Filipino philosophy. Having said these, one can now define what Filipino philosophy means.

Filipino philosophy is the Filipinos' "view" of the "world" worldview. In the local languages, the Filipino worldview is expressed as Pananaw-sa-buhay in Tagalog, Panlantaw-sa-kinabuhi in Cebuano, Pagtanaw-sabuhay in Bicol, and Pinagtanaw-ti-biag in Ilocano. The common indigenous term used in all of the languages is the term tanaw (view) and the term buhay (life). The word tanaw (view) is chosen over the word tingin (look) with respect to life because when one looks at life, one merely sees what is "happening" in one's life, but when one views life, one searches for the "ultimate meaning" of one's life. The word buhay (life) is used instead of the term mundo (world) because the term mundo is not an indigenous Filipino word but only a translation of the Latin term mundi. The term pilosopiya is not considered as an equivalent of the term pananaw-sa-buhay

$$
7 .
$$

${ }^{18}$ Romualdo Abulad, “Contemporary Filipino Philosophy,” in Karunungan, 5 (1988),

(C) 2014 Emmanuel D. Batoon

http://www.kritike.org/journal/issue 14/batoon june2014.pdf

ISSN 1908-7330

$(\mathrm{cc}) \mathrm{BY}-\mathrm{NC}$ 
because of its Greek origin. Besides this, Filipinos use the term pilosopo to refer to an "individual who is anti-social and non-conformist"19 or to a person who lacks politeness in speaking.

Having explained Mercado's theoretical framework in understanding Filipino philosophy, his method of studying Filipino philosophy can now be discussed.

\section{Method: Ethnography}

Mercado abandoned the use of the traditional academic philosophical method of research and opted for a research method that is capable of interpreting a group of people's empirical cultural worldview in a "holistic" way. This "holistic" methodology is "ethnography" (ethno, meaning "people" and grapho, meaning "writing"). Ethnography is both a process and a product. As a process, it is understood as a set of procedures in interpreting the whole life of a group of people. As a product, it is understood as a holistic report on the interpretation of the life of a group of people. By implication, Mercado's ethnography is his holistic report on his interpretation of the "the elements" that comprise the Filipino worldview. In the next section, the results of Mercado's ethnography of the Filipino worldview will be discussed. In the mean time, one may ask, "What is the guaranty that Mercado's ethnography really gathered the elements of the Filipino worldview?" To learn the answer, one has to understand Mercado's procedure.

His first step was to identify Filipinos as groups of people and not as mere sum of individuals who would serve as subjects of his study. He decided to focus on ethnicity as basis of people's grouping because ethnicity gives them a collective cultural mental frame.

Then, he chose a sample of ethnic groups because it is impossible for him to make a census of the entire population of Filipino ethnic groups. He purposefully selected ${ }^{20}$ (in contrast to statistical random selection) ethnic groups that could typify the entire population of ethnic groups in the Philippines based on size. He, therefore, selected three ethnic groups - the Tagalog, Cebuano Visayan, and Ilocano. But how could he generalize about the whole population using three ethnic groups only? Though he was not able to (and could not) make a quantitative statistical generalization because he used qualitative purposeful samples and not probability samples, he could

${ }^{19}$ Mercado, Elements of Filipino Philosophy, 96.

${ }^{20}$ John W. Cresswell, Research Design: Qualitative, Quantitative, and Mixed Methods Approaches $2^{\text {nd }}$ ed. (Thousand Oaks, California: Sage Publications, Inc., 2002), 185.

(c) 2014 Emmanuel D. Batoon

http://www.kritike.org/journal/issue 14/batoon june2014.pdf

ISSN 1908-7330 
still make a qualitative moderatum generalization ${ }^{21}$ because he saw the "transferability" of his conclusions about the three ethnic groups to the other ethnic groups in the Philippines on the ground that the three selected ethnic groups share a common ancestry (Austronesian) ${ }^{22}$ with the other ethnic languages.

To empirically ground, not just conceptually argue, the ethnic groups' worldviews, Mercado looked for empirical indicators that could help him observe the ethnic groups' worldview-language and social behavior. But what is it in language and behavior that makes them credible empirical indicators of the Filipino worldview?

The Filipino language empirically indicates the Filipino worldview because the Filipino language is not just an external sign of the Filipino thought but it is constitutive of the Filipino thought. The categories of words and the patterns of arrangement of words in the Filipino language are homologous with the Filipino mental categories and patterns of arrangements of concepts.

If the Filipino language "says" the Filipino thought, then the Filipino behavior "shows" the Filipino thought. This is so because Filipino behavior is not a natural instinctual behavior but an artificial learned behavior that is why we call them "gestures." Gestures are organized, patterned, and regulated behavior that shows the common cultural mental frame of a group of people. This system of behavior is unique because it distinguishes the way Filipinos organize their world compared with how other peoples like the Americans and the Chinese arrange their worlds.

Mercado used social behavioral data that he obtained from emic observations of Filipino behavior in his numerous missionary assignments (equivalent of fieldwork). Mercado's emic observation is unlike the detached observation that a tourist makes on other people's lives but a participant observation of a people's own view of their lives. The social behavioral data is meant as a basis for comparison to check if the people actually "do" what they "say" they do. He also validated his observations with the observations of renowned Filipino social scientists' of Filipino social behavior, which he gathered from secondary documentary data. To further make his data more reliable and compelling, he triangulated his linguistic and behavioral data with secondary documentary data on Philippine myths from the studies of social scientists because myths legitimize a people's constructed social order.

Eventually, Mercado analyzed his ethno-linguistic data using a modified version of Madeleine Mathiot's meta-linguistic methodology to

${ }^{21}$ Geiff Payne and Malcolm Williams, "Generalization in Qualitative Research," in Sociology, 32 (2005), 296.

${ }^{22}$ Mercado, Elements of Filipino Philosophy, 10.

(C) 2014 Emmanuel D. Batoon

http://www.kritike.org/journal/issue 14/batoon june2014.pdf

ISSN 1908-7330

(cc) BY-NC 
see what is "thought" behind what is "said" by the Filipino languages. He cross-checked his linguistic results with the results of his analysis of Filipino social behavior using a phenomenological methodology to ascertain that what is "shown" is really "lived" because what is "lived" is what is really "thought." He further verified his analysis of Filipino language and behavior by comparing it with the social scientists' analysis of Philippine myths from the gathered secondary documentary data. Hence, we can say that Mercado made a rigorous analysis of his data in order to describe the elements of Filipino cultural philosophy.

After learning about Mercado's ethnographic method, the discourse now dwells on his findings on the elements of Filipino philosophy.

\section{Findings: Elements of the Filipino Worldview}

\section{Logos: Filipinos' Mode of Constructing a World}

Using technical language and formal logic, western academic philosophers argued about what "should be" the nature of human knowledge. Ancient-medieval philosophers, who conceived of philosophy as a science of being, believed in reason as the instrument of knowledge that performs increasing degrees of abstraction in discovering the "essence" of a being that exists in itself and by itself. Hence, they defined knowledge as the copy of the "essence" of a being in the mind of man and declared that truth is the correspondence of the copy of the essence of a thing in the mind of man with the behavior of the thing in itself and by itself.

Modern academic philosophers realized that man cannot know the "essence" of a being in itself and by itself (noumena) but can only know beings as they appear to his mind (phenomena). So the task of man's mind is to construct concepts to constitute the "essence" of phenomena and man's reason to invent ideas about the noumena to regulate the constructed concepts. The mind no longer abstracts the "essences" of things but constructs them through the use of its innate categories of sensibility and understanding. Because of this, the epistemological concern shifted from concern for truth of ideas to concern for meaningfulness ${ }^{23}$ of concepts.

Contemporary academic philosophers continued the discourse on the nature of human knowledge by asserting that knowledge is not possible without language. Hence, the focus is no longer on the construction of concepts and invention of ideas but on the "saying" of what can be said and on the "not-saying" of what cannot be said. Hence, the epistemological

${ }^{23}$ Tassi, "Modernity as Transformation of Truth into Meaning," 185-194.

(c) 2014 Emmanuel D. Batoon

http://www.kritike.org/journal/issue 14/batoon june2014.pdf

ISSN 1908-7330 
concern shifted from the meaningfulness of concepts to the meaningfulness of linguistic expressions.

Basing from ordinary Filipino language use and observed social behavior, Mercado finds that the Filipino thinks in a social psychological ${ }^{24}$ way. Social-psychological thinking is a thinking that is focused on the needs and motives of group life. It is concerned about a knowledge that satisfies a group of people's need to establish, maintain, and develop group life. It is a knowledge production based on active involvement or participation of people. It is a process of revealing oneself and sharing the inner world of another self that leads to interpersonal communion. The tool used is intuition that involves "sense" induction, ${ }^{25}$ which is a "holistic view and a non-dualistic way of thinking" 26 about a "person" as a subject.

Filipinos embody their knowledge of interpersonal relationship in poetic language ${ }^{27}$ and gestures. Poetic language is a man-made means of communication, which does not function as a referential sign that points to an object outside of itself but as a reflexive symbol that passionately communicates the value of human relationships through the use of an image. The Filipinos' use of poetic language does not occur in a vacuum but in a range of gestures that provides essential background to such a language. A gesture is not a natural action that is instinctually performed as a reaction to an external stimulus but is a man-made action that is intuitively performed for the purpose of responding meaningfully to other people's invitation to establish, maintain, or develop an interpersonal relationship. These poetic language and gestures are learned by way of social imitation, ${ }^{28}$ through a process of socialization.

After discussing the Filipinos' social psychological way of thinking, Mercado discusses how this way of thinking conditions Filipinos' construction of their reality.

\section{Ontos: Filipinos' Construction of a World}

Ancient-medieval academic philosophers think that there are two categories of things. The first is the category "substance" which is understood as a thing that exists in itself and by itself because it has an "essence" (manner of being) and an "esse" (act of being). The second category is the "accident," which is understood as a thing that exists by

\footnotetext{
${ }^{24}$ Mercado, Elements of Filipino Philosophy, 83.

${ }^{25} \mathrm{Ibid}$., 85.

${ }^{26}$ Ibid., 79.

${ }^{27}$ Ibid., 79.

${ }^{28}$ Ibid., 81-82.
}

(C) 2014 Emmanuel D. Batoon http://www.kritike.org/journal/issue 14/batoon june2014.pdf ISSN 1908-7330 
virtue of a substance because it merely modifies a substance in terms of quantity, quality, and relation, to name a few.

Modern academic philosophers think that man's reason can never know things in themselves (substances) but man's mind can construct concepts that constitute "phenomena" (things as they appear to consciousness) through the use of the mind's categories of sensibility and understanding. To regulate the constructed concepts about the "phenomena," reason can invent ideas about the "noumena" (substances) that lie behind the "phenomena."

Contemporary academic philosophers find that the study of the categories of things into substances and accidents is a stupid non-sense because it is an attempt to "say" what "cannot be said." They also find that though the modern philosopher's concern for the study of the categories of the mind that serve as the condition of possibility for the construction of concepts that constitute phenomena and reason's invention of ideas of "noumena" that regulate concepts about "phenomena" different s' concern for substances and accidents, they still commit the same error of presuming that what can be "thought" about is separate from what can be "said." For contemporary philosophers, the more appropriate concern for being is the study of the linguistic categories "on" or "in" being.

Filipinos do not problematize the categories of being, nor the categories of the mind on being, nor the linguistic categories "on" or "in" being because they follow a social psychological way of thinking. What matters to Filipinos is the category of interpersonal relationship and the modes through which it is established, maintained, and developed.

\section{a. Anthropos: Man as Individual}

Ancient-medieval academic philosophers define man as a substance that exists in itself and by itself. As a substance, man is composed a body, the potential principle, and the soul, the active principle. The soul of man has vegetative, sensitive, and rational powers.

In contrast, modern academic philosophers delineate man as a transcendental logical subject that constructs concepts that constitute the meaning of "phenomena" and invents ideas of the "noumena" that regulate the constructed concepts. They think that the soul is nothing but an idea invented by man's reason to regulate their concept of man as a transcendental logical subject.

Contemporary academic philosophers, on the other hand, argue that the concept of man is a linguistic construction through narration and discourse. 


\section{MERCADO'S ANTHROPOLOGICAL PERSPECTIVE}

With Filipinos' social psychological concern for the establishment, maintenance, and development of their interpersonal relationships, they had to construct a knowledge of man (tao) as an individual that satisfies this concern. So they constructed the idea of individual man as a loob. This loob is holistic because it is a unified self of intellect, emotions, will, and ethics. It is interior because it is a self that lies within every man; at the same time, it is embodied, which is why Filipinos conceive the "nose" as expressive of pride.

After conceiving man as a loob, Filipinos are able to construct a generalized modal Filipino personality. But they also thought that this personality can only be actually constituted and stabilized through social life.

\section{b. Socius: Society}

Ancient-medieval academic philosophers focus on defining the substance of society. They define society as a "union of a plurality of persons in pursuit of common good."

Modern philosophers presume that human reason cannot know the nature of society as a thing in itself. Therefore, they focused their attention on the epistemological condition of possibility of the occurrence of social life. Some of them hypothesized that social life is a social contract among individuals that originated from their fear for life, limb, and property in the hostile state of nature, but some of them contend that social life is a categorical imperative of reason.

Contemporary academic philosophers find useless the attempt to explain the ontological nature of society or the epistemological origin of social life because these concerns have been replaced with the concern for the description and explanation of the empirically observable and measurable social life, which is addressed by modern social science. So contemporary academic philosophers focus instead on studying the language of social science or on theorizing about social communication and emancipation.

Filipinos are interested in providing an understanding of society that supports their psychological need for constituting and stabilizing individual subjects (loob). By consequence, Filipinos conceive society as a sakop. ${ }^{29} \mathrm{~A}$ sakop is a substantive community of persons as distinct from a functional or professional organization. Filipinos mold their sakop through a familial organization, property arrangement based on stewardship, substantive legal formulation, and familial political arrangement.

${ }^{29}$ Ibid., 97.

(C) 2014 Emmanuel D. Batoon

http://www.kritike.org/journal/issue 14/batoon june2014.pdf

ISSN 1908-7330

$(\mathrm{Cc}) \mathrm{BY}$-NC 


\section{1) Family}

The primary way through which Filipinos organize their society as a sakop or community is through a familial organization based on blood relations..$^{30}$ Part of their family organization is that "sexual distinction is not much significant as bilateral relation" 31 between the sexes is. In this way, they believe that no unnecessary stain is given in their interpersonal relations. But while sexual difference is not so much stressed, seniority ${ }^{32}$ is because the elder members of families are recognized to be the most experienced in interpersonal relationships and, therefore, the keepers of local knowledge and tradition on interpersonal relationships.

Filipinos extend their family organization-based consanguinity by including relations based on affinity (compadrazco system ${ }^{33}$ ).

\section{2) Property}

Filipinos further organize their sakop as a community in terms of property arrangement based on the idea of stewardship ${ }^{34}$ of nature. They understand that they can never possess nature because nature preceded them; they can only have "rights over its use," 35 which is why they consider "land as free goods while crops are not." 36 In so doing, no unnecessary strains are created in their interpersonal relationships because no one is deprived of the wealth of nature

\section{3) Law}

Filipinos also show their sense of community in the kind of laws that they make. Filipinos' customary laws (adat) ${ }^{37}$ are substantive laws that set their duty ${ }^{38}$ to preserve their interpersonal relationships in contrast to instrumental laws that regulate functional/professional roles as is usually found in western nations. The Filipino customary laws eventually form the

${ }^{30}$ Ibid., 93.

${ }^{31}$ Ibid.

32 Ibid., 93.

${ }^{33}$ Ibid., 97.

${ }^{34}$ Ibid., 146.

35 Ibid., 143

${ }^{36}$ Ibid.

${ }^{37}$ Ibid., 153.

${ }^{38} \mathrm{Ibid} ., 148$. 
"unwritten tradition of their ancestors," 39 which is supposed to be handed down from generation to generation.

4) Politics

Filipinos continue to mold their group as a community through their political arrangement by using a familial framework. Thus, the leader is the ama (father) or ina (mother) and the members are the anak (children) and the elders are the advisers of the leader. To objectify this familial political organization, they use the metaphor of the body. The leader is the head (pangulo) ${ }^{40}$ and the right hand man is kanangkamay ${ }^{41}$ and the other assistants as galamay. 42 Then, Filipinos "enlarge their vision of sakop so that it may embrace the whole nation." 43 Hence, the concept of sakop as a family becomes the frame through which Filipinos ultimately imagine their nation.

But the Filipino sakop needs to be further organized as a community by relating their social life with nature, with a particular location, within a temporal duration and where a synchronicity of events occurs.

\section{c. Cosmos: Man and the World of Things}

Ancient-medieval philosophers arrived at the conclusion that there are two general types of changes in the being of nature: (1) substantial change or change in what makes a thing a thing; and (2) accidental change or change in the modes of a thing in terms of space, time and causality. As a corollary to their understanding of substantial change, they would define cause as "that substance which leads to the production of another substance."

Meanwhile, modern philosophers accept that man can never know "nooumenal" change but can only conceptualize "phenomenal" change through the use of her/his mental categories of space and time that culminates in the understanding of causality as mere temporal sequence of "before" and "after".

Contemporary philosophers leave the description and explanation of nature to the positive sciences and focus instead on the analysis of the language of positive science.

From a social psychological perspective, Filipinos need to bridge the divide between their sakop and nature because the artificiality of social

\footnotetext{
${ }^{39}$ Ibid., 150.

${ }^{40}$ Ibid., 101.

${ }^{41}$ Ibid.

${ }^{42}$ Ibid.

${ }^{43}$ Ibid., 102.
}

(C) 2014 Emmanuel D. Batoon http://www.kritike.org/journal/issue 14/batoon june2014.pdf ISSN 1908-7330 
communal life has to be naturalized to grant it stability. So their focus is on how to harmonize with nature. ${ }^{44}$ In concretizing this focus, they use their concept of family as framework again. They treat nature as their parent, a caring and nurturing mother who is their refuge and protector. Conversely, they regard themselves as her children. As children, they understand that the behavior of nature is a mother's way of caring for her children. In return, they are compelled to take care of her resources, to live in harmony with her by following her laws ${ }^{45}$ and never hurting her loob by attempting to control her behavior. They also pattern the cycle of their social life after the cycle of the seasons.

\section{1) Space}

Ancient-medieval academic philosophers understand change in space as movement of a thing from one place to another place. Modern philosophers think of space as a mental category and so understand changes in space as mere changes of the mental categories of "here" and "there." Contemporary philosophers concentrate on the analysis of positive science's language on space.

Again, Filipinos think of space in a social psychological manner. This implies that they do not think of space by itself but space as a means of embedding their communal life. To do this, they humanize space by making it refer to socially meaningful places. ${ }^{46}$ Places are meaningful if and when they are associated with substantive interpersonal relationships.

\section{2) Time}

Ancient-medieval philosophers understand change in time as change in the duration of a thing's existence from existence to non-existence. Modern philosophers think of time as a mere category of the mind that measures change from "before" to "after." Contemporary philosophers focus on the analysis of the language on time.

Filipinos think of time in terms of meaningful duration of their social life. They humanize time by defining it as duration of meaningful associations. ${ }^{47}$ Time is short for those who have substantive personal relationships while time is long for those who do not have a substantive personal relationship.

${ }^{44}$ Ibid., 110-111.

${ }^{45}$ Ibid., 137.

${ }^{46}$ Ibid., 127.

${ }^{47}$ Ibid., 114. 


\section{3) Synchronicity}

Ancient-medieval philosophers think of causality as the production of a thing by another thing. Modern philosophers think that causality is just a mental temporal sequence of "before" and "after." Contemporary philosophers analyze the language of positive science on causality.

Following a social psychological thinking, Filipinos do not think of causality of things but of synchronicity ${ }^{48}$ of events. Synchronicity is a form of thinking that follows Carl Jung's ${ }^{49}$ idea of two levels of thinking. The first level is the conscious level where things are logically separated and differentiated into binaries like cause and effect relationship. The second level is the collective unconscious level where things that appear different are psychologically related and taken as similar or synchronic because they are contained in one and the same system of relations.

By implication, Filipinos may consciously think that their personal lives are logically separate and causally unrelated because they take themselves as individuals by themselves and in themselves, but their collective unconscious mind will tell them that their individual personal lives are actually psychologically synchronically related because they form part of one and the same system of interpersonal relationships or community. Filipinos further extend their idea of synchronicity of social life to the synchronicity of social and natural life. In so doing they erase the logical binary distinction between culture and nature, and let culture implode into nature and nature into culture, thus, forming a holistic worldview.

In addition to extending their kinship relations to nature, humanizing space and time, and synchronizing their social lives, Filipinos further organize their community by sacralizing it.

\section{Theos: Filipinos' Construction of a Sacred World}

\section{a. Sacred and Profane}

Ancient-medieval philosophers conceive the sacred as a supernatural supreme being, God. Modern philosophers think of the sacred as an invented idea that is used as an hypothetical or categorical object of ethical commitment. Contemporary philosophers analyze religious language on the sacred instead.

$$
\begin{aligned}
& { }^{48} \text { Ibid., } 138 . \\
& { }^{49} \text { Ibid. }
\end{aligned}
$$

(C) 2014 Emmanuel D. Batoon http://www.kritike.org/journal/issue 14/batoon june2014.pdf ISSN 1908-7330 
Filipinos think about the sacred and the profane in line with their social psychological need to foster solidarity in their community. To do this, they formulate conceptions about God, spirits, dead ancestors, and the soul.

\section{b. God}

Ancient-medieval academic philosophers argue over the existence or non-existence of a supreme being called God. This philosophical theme is called "theodicy" as distinguished from the term "theology." Modern academic philosophers think that the Ancient-medieval philosophers' concern for "theodicy" makes it appear that the problem of God's existence is God's. For modern philosophers, the problem of the existence of God is man's problem, not God's. So they changed the question from "whether or not God exists" into "whether or not it is reasonable for man to believe that God exists." This eventually changes the nomenclature of the philosophical theme "theodicy" to "philosophy of religion." Contemporary academic philosophers argue that philosophy should focus on the analysis of religious language instead.

Filipinos do not argue about the existence of God because they do not have a social psychological need for it. Instead they "intuit" the existence of $\operatorname{God}^{50}$ to identify a central subject that binds their intersubjective or interpersonal relationships in the sakop. In this way, they sacralize or set apart their collective artificial interpersonal relationships from their profane or ordinary individual natural animal lives. Their myths tell about the sacrality of their interpersonal relationships by telling that God is high and up above individual men and women and is the producer of nature (Maykapal).51 Those who would not recognize the sacrality of the interpersonal relationships within the sakop are understood as anti-social and are reduced to the level of profane individual animals who are called by animal names like snake (ahas), crocodile (buwaya), and pig (baboy), to name a few.

c. Spirits

Though Filipinos think of God as remote from ordinary men and women because God is high and up above them, Filipinos think that God is still accessible through the help of intermediaries ${ }^{52}$ - the spirits ${ }^{53}$ because they "live on trees and other places (like mountains)," 54 "guard the forces of

\footnotetext{
${ }^{50}$ Ibid., 167

${ }^{51}$ Ibid.

52 Ibid., 97.

${ }^{53}$ Ibid., 172

${ }^{54}$ Ibid., 126
} 
nature"55 and serve as patrons of "harvest, hunting and even childbearing." 56

Filipinos' idea of spirits sacralizes the people who function as intermediaries in establishing, maintaining, and developing their interpersonal relationships. Filipinos call them "big man" 57 as opposed to the "small man." 58 Their "bigness" is symbolically represented by their living on trees, thus, being able to see the whole forest, guarding the forces of nature, and acting as patrons of social activities. But sometimes these supposed intermediaries promote their own interest instead. That is why Filipinos classify spirits into "good spirits and bad spirits." 59 The bad spirits are the reasons for "sickness and misfortune" 60 of people because instead working to establish, maintain, and develop interpersonal relationships, they destroy interpersonal relationships.

\section{d. Dead Ancestors}

Filipinos sacralize their dead ancestors (anitos) ${ }^{61}$ by believing that they are not really gone but are actually alive in the other world (kabilang buhay) and are watching over them and guarding them from harm. With this construction of their dead ancestors, the fear of the members of the sakop is assuaged when they suffer the rupture of their interpersonal relationships due to the death of a kinsman, and they are eventually motivated to re-establish their interpersonal life. The Filipinos' belief in their dead ancestors is shown when they offer them food and drinks like when Ilocanos offer food (atang) ${ }^{62}$ to their dead ancestors.

\section{e. Soul of a Living Man}

Filipinos construct a social psychological way of subjectivizing or interiorizing their sakop by identifying it with the soul of a living man and conceiving it as the "double" (kakambal) ${ }^{63}$ of the physical body which they in turn conceive as signifying the individual member of the sakop. Filipinos believe that the soul of the living man or double of the physical body, which stands for the sakop, accompanies and provides for the individual member

\footnotetext{
${ }^{55}$ Ibid., 172

${ }^{56}$ Ibid.

${ }^{57}$ Ibid., 98

${ }^{58}$ Ibid.

${ }^{59}$ Ibid., 172.

${ }^{60} \mathrm{Ibid}$.

${ }^{61}$ Ibid., 173.

${ }^{62} \mathrm{Ibid}$.

${ }^{63} \mathrm{Ibid}$.
}

(C) 2014 Emmanuel D. Batoon http://www.kritike.org/journal/issue 14/batoon june2014.pdf ISSN 1908-7330 
as long as s/he lives. In this way Filipinos are able to conceive "the soul of a living man as different" 64 from the "soul" understood as kalag/kaluluwa/kararua which refers to a disembodied spirit of ghost." 65

After Filipinos sacralized their interpersonal life in the sakop, they had to moralize this sakop to grant it ultimate consolidation and stability.

\section{Ethos: Filipinos' Construction of a Moral World}

Ancient-medieval academic philosophers base their formulation of their ethical theories on three presuppositions: 1) existence of human nature, 2) existence of God as the author of human nature, and 3) existence of human freedom in human nature. From these presuppositions the academic philosophers formulate the ethical concepts of human acts, human end, and human means towards the human ends.

Since modern academic philosophers think that man can never know the nature of things, nature cannot be used as the basis of ethical life. Instead, they propose that human consciousness be used as the condition of possibility for ethical theorizing. They formulate either a utilitarian/emotive ethics which are forms of hypothetical ethics or a categorical ethics in the form of an imperative of duty.

Contemporary academic thinkers refuse to engage in formulating narratives about ethical life. They rather focus on meta-theorizing, which concentrates on determining the reasonability of socio-cultural ethos or on the condition of possibility for formulating a universal ethics.

Given Filipinos' social psychological way thinking, they understand ethics as the ultimate means of consolidating and stabilizing their interpersonal relationships in the sakop after it has been sacralized because it sets the moral rules on how to behave in the sacred sakop. To objectivize this ethos, they construct a number of things.

They start with the psychological condition of possibility for moral life to exist in their sakop by focusing on man as loob. They regard that if the loob is something interior, then their ethos must also proceed from this interior life. In this way, ethical life is not imposed from the outside but voluntarily wells out from within an individual man. Filipinos understand this overflowing characteristic of man's loob as "innate goodness."

Then they formulate the norm of morality that arises from the idea of the loob's innate goodness-awa $a^{66}$ (mercy). Awa is both a passionate recognition of the existence and active valuing of the loob of an other. By implication, a social act is moral when it is merciful, and a social act is

${ }^{64}$ Ibid., 71.

${ }^{65}$ Ibid.

${ }^{66}$ Ibid., 275.

(c) 2014 Emmanuel D. Batoon http://www.kritike.org/journal/issue 14/batoon june2014.pdf

ISSN 1908-7330 


\section{MERCADO'S ANTHROPOLOGICAL PERSPECTIVE}

immoral if it is cruel, i.e., when it ignores or negates the existence and value of the loob of an other.

Through merciful acts, the sakop is maintained and developed while cruel acts lead to the breakdown of social life. Merciful acts are encouraged while cruel acts are discouraged by means of a system of reciprocity ${ }^{67}$ or utang na loob, roughly translated as "debt of volition." 68 When an individual does good to another individual, the individual who benefits from the good act of the other individual incurs a debt of volition and is obliged to return the favor in due time. Conversely, an individual who does bad to another individual, incurs a debt of volition and is obliged to pay back or compensate the loss of the other individual.

A debt has to be paid (re-tribute-ion), ${ }^{69}$ otherwise, the balance and harmony of the interpersonal relationships in the sakop will not be restored or maintained. If an individual does not pay her/his debt, this will bring her/him shame ${ }^{70}$ and she/he will be cursed $(g a b a) .{ }^{71}$ Shame and humiliation mean that an individual member is excluded from interpersonal relationships, loses face, and is reduced to the level of an animal.

But an individual who is not able to pay for her/his whole debt despite her/his best efforts is not necessarily banished from communal life. She/he can "leave what is beyond her/his strength to God."72 This is the attitude of bahala $n a,{ }^{73}$ which is not synonymous to "fatalism" but should be understood as letting go and letting God. This is the attitude of expecting mercy (awa) from the sakop (for whom the concept God ultimately refers), for 'forgiveness' (tawad) from her/his remaining debt because the sakop understands that she/he did not really intend to hurt the sakop but was able to do so because of sheer difficulty in fulfilling the requirements of living a collective artificial rational communal life that runs counter to the dictates her/his natural instinctual animal desires.

With the discussion of Mercado's findings on Filipinos' construction of a moral world, the justification of the significance of Mercado's anthropological perspective on the study of Filipino philosophy has been completely traced. What remains to be done is to defend its significance against other scholars' criticisms and to reinforce its significance by probing into other scholars' approval of his perspective.

Department of Philosophy, University of Santo Tomas, Philippines

\footnotetext{
${ }^{67}$ Ibid., 97.

${ }^{68}$ Ibid.

${ }^{69}$ Ibid., 185.

${ }^{70}$ Ibid., 180.

${ }^{71}$ Ibid., 182.

${ }^{72}$ Ibid.

${ }^{73} \mathrm{Ibid}$.
}

(C) 2014 Emmanuel D. Batoon

http://www.kritike.org/journal/issue 14/batoon june2014.pdf

ISSN 1908-7330

(cc) BY-NC 
$\sim$ To be continued in Volume Eight Number Two (December 2014)

\section{References}

Abulad, Romualdo, "Contemporary Filipino Philosophy," in Karunungan, 5 (1988).

Batoon, Emmanuel D., A Guide to Thesis Writing in Philosophy Part One: Proposal Writing (Manila: REJN Publishing, 2005).

Cresswell, John W., Research Design: Qualitative, Quantitative, and Mixed Methods Approaches $2^{\text {nd }}$ ed. (Thousand Oaks, California: Sage Publications, Inc., 2002).

Demeterio, F.P.A. III, “Re-reading Emerita Quito's Thoughts Concerning the Underdevelopment of Filipino Philosophy," in F.P.A. Demeterio's Philosophy and Cultural Theory Page (April 2002), $<$ https://sites.google.com/site/feorillodemeterio/filipinophilosophyes says $>$.

Hoebel, Adamson E. and Everett L. Frost, Cultural and Social Anthropology (New York: McGraw-Hill Book Company, Inc., 1976).

Jocano, Felix L., Filipino Worldview (Quezon City: PUNLAD, 2001).

Mercado, Leonardo N., Elements of Filipino Philosophy (Tacloban City: Divine Word University Publication, 1974).

Neuman, W. Lawrence, Social Research Methods Qualitative and Qualitative Approach $6^{\text {th }}$ ed. (Boston: Pearson Education, Inc., 2006).

Payne, Geiff and Malcolm Williams, "Generalization in Qualitative Research," in Sociology, 32 (2005), 296.

Radin, Paul, Primitive man as philosopher (New York: Dover Publications, Inc., 1957).

Reyes, Ramon C., "Sources of Filipino Thought," in Philippine Studies, 21 (1973).

Tassi, Aldo, "Modernity as Transformation of Truth into Meaning," in International Philosophical Quarterly, 22 (1982). 